Anuario Latinoamericano Ciencias Políticas

y Relaciones Internacionales

vol. 10, 2020

pp. $121-146$

\section{Burning Bridges and Defending the Faith. The Troubled Brazil-China Partnership in the Bolsonaro Era}

DOI:10.17951/al.2020.10.121-146

\section{Quemando puentes y defendiendo la fe: la relación turbulenta entre Brasil y China en la era Bolsonaro}

\author{
Monika Sawicka* \\ INSTITUTE OF AMERICAN STUDIES AND POLISH DIASPORA \\ JAGIELLONIAN UNIVERSITY \\ CRACOW, POLAND \\ $\triangle$ monika.sawicka@uj.edu.pl \\ https://orcid.org/0000-0002-8889-6061
}

\begin{abstract}
This paper contends that major foreign policy shifts of the Bolsonaro government, which led to a redefinition of Brazil's foreign policy narrative and international roles, triggered tensions in Sino-Brazilian relations. The main theme of Brazil's recent troubled partnership with China is explored by scrutinizing ideational underpinnings of Brazil's foreign policy. Therefore, emphasis is placed on the modifications of discursive self-articulation implemented by the country's foreign policy elites with a particular focus on a new understanding of the West and Brazil's western sense of belonging. A redefined self-conception, resulting in the embracement of the roles of a faithful ally of the United States and defender of the faith has not failed to impact Brazil's cooperation with the challenger of the liberal world order, China. The analysis of Brazil's recent external activism is anchored in role theory and builds on a constructivist approach to foreign policy analysis (FPA).
\end{abstract}

KEYWORDS: Brazil, China, roles, identity, the West, Bolsonaro government.

\section{RESUMEN}

Este trabajo sostiene que los cambios profundos de la politica exterior del gobierno de Jair M. Bolsonaro llevaron a una redefinición de la narrativa de la política exterior de Brasil y de sus papeles internacionales, provocando tensiones en las relaciones sinobrasileñas. El tema principal de la asociación problemática de Brasil con China se

* M. A. and Ph. D. in Political Science from the Jagiellonian University. Assistant Professor at the Department of International and Political Studies, Institute of American Studies and Polish Diaspora, Jagiellonian University. 
Dossier América Latina: la iniciativa china de la Franja y la Ruta explora mediante el análisis de los fundamentos conceptuales de la política exterior del Brasil. Por lo tanto, se pone énfasis en las modificaciones de la autoarticulación discursiva implementada por las elites de la política exterior del país con un enfoque particular en una nueva comprensión del Occidente y del sentido de pertenencia occidental de Brasil. La autoconcepción redefinida, que ha dado lugar a la adopción de los papeles del aliado fiel de los Estados Unidos y defensor de la fe, no ha dejado de repercutir en la cooperación entre Brasil y el desafiante del orden mundial liberal, China. El análisis del reciente activismo externo de Brasil está basado en la teoría de los papeles y asume un enfoque constructivista del análisis de la política exterior (FPA).

PALABRAS CLAVE: Brasil, China, papeles, identidad, el Occidente, gobierno Bolsonaro.

\section{Introduction}

During his first year in office, Brazilian President Jair Messias Bolsonaro was at the center of the international spotlight on several occasions. After a faint and rather unnoticeable debut during the World Economic Forum in Davos, the far-right politician hit the global headlines when one of his entourage members on his trip to Osaka for the G20 Summit was caught with nearly 40 kilos of cocaine (Charner, 2019, June 26). In the summer of 2019 French President Emmanuel Macron held him explicitly responsible for the Amazon fires on an unprecedented scale. The accusations triggered a scramble between both leaders, leading to a diplomatic crisis. In the first half of 2020, however, while international media outlets were focusing on the difficult situation the country was facing due to the Covid-19 pandemic, core political actors in Brazil engaged in a new diplomatic quarrel. This time, with Brazil's biggest trading partner and important investor, the People's Republic of China.

This paper contends that major foreign policy shifts of the Bolsonaro government, which led to a redefinition of Brazil's foreign policy narrative and international roles, triggered tensions in Sino-Brazilian relations. The main theme of Brazil's recent troubled partnership with China is explored by scrutinizing ideational underpinnings of Brazil's foreign policy - the modifications of discursive self-articulation implemented by the country's foreign policy elites with a particular focus on a new understanding of the West and Brazil's western sense of belonging. A redefined self-conception, resulting in the embracement of the roles of a faithful ally of the United States and defender of the faith, has not failed to impact Brazil's cooperation with the challenger of the liberal world order, China. This paper seeks to aid the understanding of Brazilian foreign policy in the Bolsonaro era by addressing the following research questions: What were the discursive shifts in the Brazilian self-conception? How did these shifts translate into the diplomatic narrative on foreign policy and, in particular, core Brazilian partnerships? How did the new narrative impact 
Brazil's national role conceptions leading to role change? Do these reformulations impact Sino-Brazilian relations? The analysis of Brazil's recent external activism is anchored in role theory. Building on a constructivist approach to foreign policy analysis (FPA), the work emphasizes the entanglement of identities and roles and draws upon the symbolic interactionist perspective on the study of states' roles. The validation of foreign policy narratives is based on qualitative content analysis of policymaker's speeches, interviews, and social media accounts as well as publications of distinguished diplomats. The paper further refers to secondary material such as media coverage on Sino-Brazilian relations and existing scholarship on Brazilian foreign policy.

The paper starts from a brief description of the main theoretical concepts applied to the study of foreign policy - national role conceptions and national identities. The second section outlines the paradigms of Brazil's foreign policy and briefly refers to their sources: identities and national role conceptions. The following part focuses on Brazilian foreign policy reformulations after January 2019. This section includes a presentation of the major groups participating in the struggle to impact Brazilian foreign policy. The last part assesses how ideational shifts impacted the Sino-Brazilian relationship within the first 18 months of the Bolsonaro administration.

\section{Role theory in the foreign policy analysis}

Neglected for over a decade at the end of the $20^{\text {th }}$ century, role theory, and specifically the symbolic-interactionist approach to role analysis, seems to be back in vogue in FPA (Aggestam, 2006; Beneš \& Harnisch, 2015; Thies \& Wehner, 2014; Wehner, 2018; Karim, 2018; Sá Guimarães, 2020). A possible explanation for the revival of a conceptual framework developed throughout the $20^{\text {th }}$ century by sociologists and social psychologists is its virtually acknowledged capability to bridge the gap between agency and structure. Role theory acknowledges the agency of actors, individuals, or groups, and thus permits us to capture the decision-making process in foreign policy. On the other hand, this theoretical framework reflects on the anchorage of actors in social structures - be it the society or the international system - and its impact on their values and beliefs as well as policy choices. ${ }^{1}$ What further distinguishes role theory is its recognition of both material and cognitive-ideational variables as factors impacting the selection of roles by states and therefore drivers of states' behavior in the international system (Cantir \& Kaarbo, 2016; Below, 2015; Thies, 2010).

Roles are patterns of behavior or functions which states perform in the international system. These patterns of behavior are constituted and readjusted within the constant process of interactions with other actors of the interna-

1 For a detailed account of role theory's qualities see Walker, 1987; 2016; Thies, 2010; Cantir \& Kaarbo, 2016.
Burning Bridges and Defending the Faith. The Troubled Brazil-China Partnership in the Bolsonaro Era

Monika Sawicka 
Dossier América Latina: la iniciativa china de la Franja y la Ruta tional system. The role partners, the Others, hold certain (role) expectations based on the material capabilities, historic experiences of past interactions, and symbolic images of their partners. The process of adjusting these expectations to one's own cognitive-ideational and functional preferences is called the role location. Roles simultaneously reflect and impact statuses - positions within a complex and stratified world order - and national identities.

This paper focuses foremost on the close link between identities and roles as roles can be understood as the "primary manifestations of identity" (Sá Guimarães, 2020, p. 2). This relation becomes particularly visible in national role conceptions, defined by Kalevi Holsti as

policymakers' own definitions of the general kinds of decisions, commitments, rules and actions, suitable to their state, and of the functions, if any, their state should perform on a continuing basis in the international system or in subordinate regional systems. (Holsti, 1970, p. 246)

Role conceptions scrutinized from a symbolic-interactionist angle embody actors' self-perceptions - their image and identity ${ }^{2}$ in the world system (Below, 2015 , p. 28) and this perception is the outcome of an interactive negotiating process in which the Ego or the Self interprets and accommodates respectively to its image as seen by the Alter - the Other.

The dynamically growing scholarship on states' roles identifies national role conceptions through the qualitative analysis ${ }^{3}$ of policymakers' (most commonly, heads of states and ministers of foreign affairs) discursive practices constituting narratives on identity, important international partners, and strategies to reach external goals. Before we reflect on the narratives created by important stakeholders of the Bolsonaro government, we will highlight two Brazilian foreign policy paradigms dominant in the $20^{\text {th }}$ century and point out the roles and identities behind them.

\section{Competing paradigms, hybrid identities and changing roles}

José Maria da Silva Paranhos Júnior, better known as the Baron of Rio Branco,

2 We make the claim that identity exists in a national dimension and we build on the assumption that although it is carried by individuals, national identity is not reduced to a set of individual identities. If individual identities are constructed under the influence of socio-cultural practices and patterns that create in individuals a sense of belonging to a certain community, to which a collective identity shared by other members of the community will be attributed, then the category of that collective identity should be relevant and studied because it will have social consequences (Szacki, 2004, p. 31).

3 Most commonly content analysis, discourse analysis, historic analysis and, most recently, interpretive narrative analysis are applied to the study of national role conceptions (Wehner, 2018). 
the Brazilian Foreign Affairs Minister from 1902 to 1912 and well-revered founder of the state's modern diplomacy, was notorious for his sympathy towards the United States. Contrary to the position of Brazil's neighbors, the young Latin American republics that looked with distrust towards the Yankees in the North, the Baron of Rio Branco perceived the United States as a natural partner for Brazil. The Brazilian statesman endorsed the Monroe doctrine, considering it as a shield able to deter European imperialism and guarantee peace and stability within the region (Bethell, 2009). His policy, referred to as the unwritten alliance, set out Brazil's principal foreign policy paradigm valid for most of the $20^{\text {th }}$ century: Americanism. Among diplomats and statesmen supporting Rio Branco's vision were abolitionist and the first ambassador to the United States, Joaquim Nabuco, and lawyer and politician Ruy Barbosa. These intellectuals were promoters of the notion of pan-Americanism - the integration of the western hemisphere under the leadership of the US and with the US-Brazilian alliance as its central axis.

The preferred foreign policy strategy within the Americanism paradigm was bandwagoning with the rising world power. National role conceptions in line with this approach were those of a bloc member supporting the bloc leader and of a faithful ally of the United States. ${ }^{4}$ During the Cold War, Americanism translated into an alignment with the First World, the western superpower, and its European allies.

On the discursive level, Americanism was based on the claim that Brazil and its northern neighbor were alike. With the abolition of slavery (1888) and establishment of the Republic (1889) Brazil removed the main obstacles curtailing the development of a national identity narrative in which Brazil was constructed as a civilized, stable and law-abiding state, led on the international scene by the principle of peaceful resolution of conflicts. At the same time, at the turn of the centuries the Brazilian elites were increasingly aware of the cultural and economic backwardness of the young Republic. The internal discussions oscillated around the issue of centuries of miscegenation and slavery and the large proportion of Blacks of African descent in the Brazilian population, seen as factors responsible for the country's underdevelopment. At that point in time, however, the political elites considered increased migration of whites from Europe as a solution for Brazil's anachronisms, and the internal challenges did not impact the international agenda oriented towards deepening ties with the strongest player in the hemisphere (Skidmore, 1999, p. 102). Therefore, a close partnership with the United States dovetailed with the Brazilian self-articulation. At the beginning of the $20^{\text {th }}$ century, an important part of the country's elites recognized the former British colony as the positive Significant Other.

4 Its most expressive manifestation was Brazil's decision to participate in the US invasion of the Dominican Republic in 1965, even though sending its troops compromised the state's traditional values of non-interference and respect for other states' sovereignty.
Burning Bridges and Defending the Faith. The Troubled Brazil-China Partnership in the Bolsonaro Era

Monika Sawicka 
Dossier América Latina: la iniciativa china de la Franja y la Ruta
The relationship with the Significant Other was based on the assumption that Brazil was a part of the "West" by history, culture, religion and geographic location. The western affiliation of Brazil was a core element of the Brazilian elites' discursive articulations. Aware of developmental challenges related to the colonial experience, an important part of the political and intellectual elites shared the desire to articulate the Self in the image and likeness of the Other.

The narrative of the belonging to the West was not even questioned by policymakers who opted for an alternative path to position Brazil on the international stage. Such alternative was based on closer ties and solidarity with other developing states. This was the case of Jânio Quadros who implemented the "independent foreign policy" in 1961. In his manifesto on the principles of Brazilian external activism published in Foreign Affairs Quadros explained the bonds uniting Brazil with the Global South. Yet, he stressed explicitly that Brazil was a member of the West (Quadros, 1961, p. 23). This notion was also maintained by diplomats in the later years of the military dictatorship, after 1974. Although many members of Itamaraty, as the Brazilian Ministry of Foreign Affairs is commonly called, held the view that Third-Worldism was an ideology-driven foreign policy orientation, Ramiro Saraiva Guerreiro, head of the Brazilian diplomacy from 1979 to 1985, claimed that Third-Worldism expressed Brazil's factual economic condition and was therefore not a matter of ideological preferences. What was also voiced by Saraiva Guerrero was Brazil's western identity - "Brazil is a western country or at least intends or would like to be one" (Saraiva Guerreiro, 2010, p. 13).

Just as the image of the Self was reinterpreted by the state's elites over the $20^{\text {th }}$ century, so was the understanding of the West. Oliver Stuenkel from the Brazilian think tank Fundação Getúlio Vargas makes a strong claim that the notion of the West was undergoing dynamic changes, being "continuously in motion, continuously adapting to new realities, and imagined in new ways by different groups" (Stuenkel, 2011, p. 181). An original understanding of Brazil's western affiliation was proposed by José Guilherme Merquior at the end of the 1980s. His concept of "the other West" stressed that Brazil, along with other Latin-American states, was a problematic West - more enigmatic and poorer, yet nevertheless a member of the western community due to its values, languages, beliefs, and the formation of its societies (Merquior, 1990, p. 87). The late Brazilian diplomat contended that claims of Brazil's distinctiveness were part of a narrative myth, a strategy fueled by resentments developed due to frustrated attempts to reach the liberal, democratic, and modern part of the world. What stands out in Merquior's essay is the double presence of inferiority - visible in both the author's analysis of statesmen's past efforts to claim the western identity of Brazil and the acknowledgment of Latin America's idiosyncrasies as a member of the West. As will be shown in the next section, this feeling of inferiority is no longer visible in the statements of the current administration. 
Apart from the Rio Branco's era, Americanism was the leading paradigm in Brazil's foreign policy after 1942, when President Getúlio Vargas declared war against the Axis countries, the presidencies of Eurico Gaspar Dutra (1946-1950) and Juscelino Kubitschek (1956-1960), during a part of the military dictatorship - between 1964 and 1974, the presidency of Fernando Collor (1990-1992) and, to a lesser degree, Fernando Henrique Cardoso (19952002). Efforts to build a closer relationship with the United States were also visible in the Temer government (2016-2018).

What was called by Merquior a myth of Brazilian distinctiveness was indeed a powerful discourse shared by an important group of the state's policymakers, diplomats, and scholars along the $20^{\text {th }}$ century. What struck such figures as lawyer Eduardo Prado, writers Manuel de Oliveira Lima, José Veríssimo, and Manuel Bomfim already in the times of Rio Branco, was Brazil's disregard for the imperialist threat posed by the rising world power from the North. A part of those critics further disapproved of the state's neglect to forge a closer alliance with its Latin American neighbors. They inaugurated an alternative narrative present to this day in the Brazilian diplomatic discourse. It envisaged Brazil's cultural affinity with its Latin American neighbors who shared the same Iberic culture, colonial experiences, and religion. What stood out in this discourse was the Brazilian distinctiveness from European powers and the United States - Brazil was no longer the tropical extension of the European civilization in the western hemisphere nor was it the natural ally of the rising western hegemon.

The economic distinctiveness of Brazil and other Latin American states was added as a core element of the diplomatic narratives of the Brazilian elites in the mid $-20^{\text {th }}$ century due to concepts provided by researchers affiliated with the Economic Commission for Latin America and the Caribbean (ECLAC). Its first director, Raúl Prebisch, diffused the notion of the center and peripheries in the world economy. These concepts, along with dependency theory, led to the creation of an economic identity of the world periphery. Works of Prebisch, Brazilian economist Celso Furtado and sociologist Fernando Henrique Cardoso made the state's underdevelopment explicit and exposed the increasing economic gap between what came to be known as the Global North and South. Backwardness and underdevelopment were no longer associated with concepts based on scientific racism as at the beginning of the $20^{\text {th }}$ century, but with the exploitative features of the international economic framework in which the interests of former colonies clashed against those of the richest, developed states (Love, 1994, pp. 414-417).

The process of decolonization, which gained momentum after 1960, triggered an increased interest for new partnerships in Brazil. Already since the 1940s some Brazilian diplomats were raising their concerns that a close alignment with the US could limit Brazil's international activism. One such diplomat was Oswaldo Aranha, the head of Brazilian diplomacy in the Vargas government (Alencastre, 1961, p. 25). Other important voices within Itamaraty
Burning Bridges and Defending the Faith. The Troubled Brazil-China Partnership in the Bolsonaro Era

Monika Sawicka 
Dossier América Latina: la iniciativa china de la Franja y la Ruta in the 1950s included Adolpho Justo Bezerra de Menezes and José Honório Rodrigues. The first claimed that Brazil should strengthen its international standing by a closer cooperation with African and Asian states, which shared a similar worldview and values with Brazil (Bezerra de Menezes, 2012). The latter recommended an approximation with African countries, pointing out Brazil's African legacy and cultural affinity (Rodrigues, 1965). The discourse of the Brazilian elites sharing this standpoint highlighted common colonial experiences, values (such as sovereignty, autonomy, non-interference), identities (the common economic identity of the periphery and of the post-colonial subject), developmental challenges, and similar interests in international fora as opportunities for cooperation. Brazil's racial mosaic and cultural hybridity were no longer perceived as sources of backwardness but attributes enriching Brazil and potentially facilitating cooperation with the developing part of the world, the Third World. This discourse, which created a narrative to support a paradigm alternative to Americanism, questioned the close cooperation with the US due to limited returns it brought Brazil. ${ }^{5}$ The quest for deeper ties with peripheral Latin American, African and Asian states became known as the universalist or globalist paradigm in Brazilian external affairs. The foreign policy strategy applied on many occasions by governments that adopted this paradigm was soft balancing against the world leading power, whereas national role conceptions matching this approach were those of a coalition builder ${ }^{6}$ and regional integrator.

Universalism characterized the foreign policies of Jânio Quadros and João Goulart from 1961 to 1964, the "ecumenical and responsible pragmatism" policy of the military government of Ernesto Geisel (1974-1979) and his successor, João Baptista Figueiredo (1979-1985). In the $21^{\text {st }}$ century a universalist foreign policy was led by the Lula da Silva (2003-2010) and Dilma Rousseff (2011-2016) governments.

It is noteworthy that relations with China were built and developed at times when the universalist paradigm was the guiding principle of Brazil's foreign policy. President Quadros sent a trade mission, headed by his vice-president João Goulart, to the People's Republic of China in August 1961. In Beijing, the Brazilian delegation completed the negotiations on a Sino-Brazilian trade agreement, decided to open a branch of the New China News Agency and establish a Chinese trade mission in Brazil, the first one in Latin America. The trade mission did not last long, however. After the coup in April 1964, the military, distrustful of representatives of communist China in Brazil, closed

5 For instance, the close alignment with the US, a guiding principle of Brazil's foreign policy during the Dutra presidency, was coined by Gerson Moura as alignment without recompense (alinhamento sem recompensa). See Moura, 1980.

6 Brazil is a founding member of the G77. In the $21^{\text {st }}$ century, it led along with India the G20 coalition within the World Trade Organization, and it was a member of IBSA (The India-BrazilSouth Africa Cooperation Forum), the BRICS and the BASIC (Brazil, South Africa, India and China) coalition in the global debate on climate change. 
the mission and the news agency and accused nine members of the mission of "subversive activities against the national order" (Martinez, 1970, p. 82). Ten years later, the redefinition of foreign policy priorities induced the Geisel government to establish diplomatic relations with the People's Republic of China. At that point in time, Brazil's critical standing on the Non-Proliferation Treaty, the human rights protection priorities of the Carter administration and the international environmental agenda posing a threat to the industrial development of the Third World coincided with the posture of communist China (Altemani de Oliveira, 2010, p. 90). Sino-Brazilian relations reached an unprecedented level in both the political and economic sphere during the universalist policies of the Lula and Dilma administrations.

The administration of the incumbent president has shown for the past 18 months clear signs of an Americanist approach to foreign policy based on a close relationship with the United States. In order to grasp the idiosyncrasies of the Bolsonaro government and its impact on the Sino-Brazilian relations, we should first bring to light another important feature of Brazil's international identity that impacted the country's standing vis-a-vis important international partners.

In the $20^{\text {th }}$ century Brazil much of the elites' debate aimed at defining the Brazilianness oscillated around the phenomena of hybridity and mestiçagem - the biological and cultural crossbreeding triggered by Portuguese colonization and characterized by a mixture of three races. Modernist poets pointed out that historical experiences developed Brazil's anthropophagic capacity a capacity to devour external cultural influences and "brazilianize" them into unique Brazilian qualities (Andrade, 1928). This exceptional feature of Brazil evidenced a national ability to handle contradictions, make necessary adjustments (expressed in national literature as shapeshifting) ${ }^{7}$ and stimulated ambiguous discursive articulations. In the political sphere, this translated into the skill to express Brazil's affinity with the West and with the Third World. Or rather - it permitted the country to avoid exclusive commitments. Although the Americanism and universalism paradigms can be seen as contradictory, many representatives of the diplomatic and academic circles advised a more ambivalent standing. Supporters of such approach promoted Brazil's positioning in-between worlds, coalitions, and ideologies. João Augusto de Araújo Castro, one of the conceptual founders of the "independent foreign policy", contended that despite its ideological affinity with the West, Brazil should not manifest it as it could hinder the development of relations with the Third World (Araújo Castro, 2007, pp. 95-96). Hélio Jaguaribe, a prominent Brazilian sociologist and political scientist, advised Brazil neutrality as a neutral country could enact the role of a bridge and mediator between opposed blocs. Brazil was to build its international position in a way that would enable

7 The ability to shapeshift was an attribute of modernist Mario de Andrade's Macunaíma, the "hero without a character", considered a personification of the national traits of Brazilians.
Burning Bridges and Defending the Faith. The Troubled Brazil-China Partnership in the Bolsonaro Era

Monika Sawicka 
Dossier América Latina: la iniciativa china de la Franja y la Ruta it to mitigate systemic tensions resulting from the bipolar world order. While enacting the role of a bridge, the country could pursue its foreign policy goals (Jaguaribe, 2013, pp. 325-327). Such strategy also allowed the state to maintain flexibility, increasing its options and choices in the international system (Soares de Lima, 1996, p. 144).

Examples of Brazil's moderate approach towards bloc affiliations can be found in periods of both Americanism and universalism. After the military coup in April 1964, the new government of Humberto Castelo Branco did not change the instructions for the Brazilian delegation at the UN Geneva Conference on Trade and Development (Santos, 2002, p. 40). The event witnessed the creation of the G77, a group of developing states sharing common economic interests and negotiating positions. An expression of Brazil's international standing suspended between blocs and alliances was the decision not to join the Non-Aligned Movement (NAM) as a permanent member, but to maintain the observer status. In both the NAM and the G77 Brazil manifested moderate positions. The country's policymakers avoided support for attitudes which could be perceived by members of the Global North as confrontational, and within the G77 engaged in coordinating efforts aimed at a formulation of demands acceptable for the developed states (Selcher, 1978, pp. 281-285).

The ability to avoid clear commitments and stay within the sphere of ambivalence was best manifested during episodes of pragmatic equidistance (Moura, 1980), also described as pendular diplomacy (Gambini, 1977). Such was the policy adopted between 1932 and 1942 by the Vargas administration towards the United States and Germany. At the beginning of World War II, the Vargas government declared neutrality, a position which gave Brazil the leverage in economic negotiations with both blocs until the beginning of 1942. Until that moment the Vargas government managed to maintain extensive trade exchanges with both Nazi Germany and the United States. Pragmatic equidistance was also the approach Brazil assumed in the Israeli-Palestinian conflict from 1947 to 1973 , refusing to take sides.

In a recent article published in Foreign Affairs Latinoamérica its authors consider the tension of the Trump administration and Xi Jinping's China as the new Cold War. Assessing the optimal strategy for Latin America, Carlos Fortín, Jorge Heine and Carlos Ominami recommend active non-alignment. Avoiding clear commitments and not taking sides could be the best option for countries of the region in trade and technological quarrels between both powers, proving the maturity of their foreign policies. The authors also explicitly call for Latin America's equidistant position in matters of world politics (Fortín, Heine \& Ominami, 2020, pp. 112-114). The next two sections of the article will assess whether the Brazilian administration is willing to follow this advice. 


\section{The new narratives of the "new foreign policy"}

The Bolsonaro administration embarked on the project of revising and recreating foreign policy priorities, strategies, and concepts. The depth of this shift reaches national values, ideals, and desires translated into foreign policy objectives. On the $1^{\text {st }}$ of January 2019, in his inaugural address in front of the Congress, President Jair Bolsonaro confirmed that Brazilian foreign policy would be sovereignty-driven, focused on development and the construction of grandeza (Bolsonaro, 2019, January 1), referring to three hardly controversial and traditionally acknowledged foreign policy goals. Ernesto Araújo, the new minister of foreign affairs, delivered a message of changes. In his exposé on the $2^{\text {nd }}$ of January, Araújo inaugurated "a new foreign policy". His speech made it clear that Brazil was looking forward towards a strengthened relation with the United States and other states ruled by right-wing conservative governments: Hungary, Poland, Italy, and Israel. What stands out is a lack of any reference whatsoever about the state's BRICS partners, until now mentioned on such occasions as important allies in global political, financial, and trade negotiations and, particularly relevant in the case of China, investors and buyers of Brazilian goods (Araújo, 2019, January 2). After 18 months it becomes clear that the omissions in both Bolsonaro's and Araújo's inauguration speeches were symptomatic of Brazil's new foreign policy. Except for its ideological content justifying a radicalized version of Americanism - an unconditional alignment - it is not clear what the goals, priorities, and strategies of the new administration are (Chagas-Bastos and Franzoni, 2019, October 16).

The Americanist policy implemented after 2019 was to differ significantly from previous periods. The head of the Brazilian diplomacy in his inaugural address introduced a new meaning of Brazilianness and with it, of the West. The discourse of Araújo looms with the vision of a Brazil that regains its identity constituted by nationalism as opposed to globalism, Christian faith, the values of God, the family, freedom, and reverence for a mythical past and national symbols (Araújo, 2019, January 2). Both the head of state and head of Itamaraty make it clear that Brazil is a member of the West, although the image of the West is significantly reinterpreted. In a paper published in 2017, titled "Trump and the West", Araújo presents the vision of a threatened West. Occidentalism is in deep crisis and the author makes it clear that it not the economic or military capacity that define the West, but its values, and those are endangered in the clash of civilizations (Araújo, 2017). The great threats to western civilization are: globalization defined as a nihilist force; the discredit of nationhood; political correctness critical of national values, symbols and heroes; supranational institutions and blurred borders epitomized in the European Union; cultural Marxism and communism (Araújo, 2017; 2019, June 10). The decadence of the West can be inhibited by the Trump administration and Brazil is perceived as an important ally in this fight. The notion that Brazil participates in a civilizational war was explicitly outlined in
Burning Bridges and Defending the Faith. The Troubled Brazil-China Partnership in the Bolsonaro Era

Monika Sawicka 
Dossier América Latina: la iniciativa china de la Franja y la Ruta a speech delivered at the Heritage Foundation in September 2019: "So Brazil is back (...) we feel we are back to the center of the fight. We may say that Trump and Bolsonaro are part of the same insurgency, what I would call the universal insurgency against bullshit (...) it's a revolt against ideology [of globalism M.S.]" (Araújo 2019, September 11). ${ }^{8}$ What stands out in the new narrative is Brazil's strong position within the West - the country's "essence is occidental" (Araújo, 2017, p. 354). The country is depicted as a member of the avant-garde movement that has the potential to save the West. This vision departs significantly from the notion of "the other West" with an ingrained sensation of inferiority. "Europe does not possess a monopoly over this western adventure; we are just as much or more part of that story. I say precisely that the West is not only about Europe" (Araújo, 2019, December 13).

The strong affiliation with the Occident and national role conception of the defender of the faith and faithful ally ${ }^{9}$, which clearly emerges in the diplomat's discourse, requires an unambiguous affiliation. Araújo criticized past approaches towards maintaining autonomy in foreign affairs that were based on an ambiguous standing - avoiding clear submissions to blocs: "We viewed with great suspicion the idea to integrate a West that necessarily excludes other civilizations and that would leave us stuck within a certain block" (Araújo, 2017, p. 354).

And how does the People's Republic of China dovetail with this new foreign policy narrative? During the presidential campaign Jair Bolsonaro adopted a hostile rhetoric towards communist China. His famous tweet that Beijing is not "buying in Brazil - it is buying Brazil" dates back to 2018 and the politician stressed on numerous occasions the urge to redefine the relationship with China and distance Brazil from its BRICS partner. As head of state, along with his head of diplomacy, Bolsonaro underlined the necessity to reframe the economic ties with the People's Republic of China, or, in the words of Ernesto Araújo - restructure the relationship with China to become more symmetrical (Araújo, 2019, December 13). References to communist threats, although focusing mainly on the Latin American context, were contributing to interpretations of China as the negative Significant Other in Brazil's cognitive map. China was not a part of the West and therefore could be seen as an adversary in the civilizational struggle in which Brazil, according to a part of the political elites, was participating. A visibly hostile image of China was presented in his lecture to young diplomats at the Rio Branco Institute, Brazil's famous diplomatic school. The relations with China were assessed as mistaken, like other partnerships with the Global South. Araújo was critical of focusing foreign

8 Political scientist Feliciano de Sá Guimarães contents that Brazil's close relationship with the United States should be understood more precisely as a close relationship with the Trump administration. Therefore, in case the political leader changes, Brazil would redefine its ties with the US (Sá Guimarães, 2019, November 20).

9 Governments that embraced the role of the defender of the faith were committed to defend value systems and ideological purity in the international system (Holsti, 1970, p. 264). 
policy on its commercial side: "we will not sell our soul to China" (Araújo, 2019, March 11). Such statement could have come as a surprise to the audience as President Bolsonaro focused his message to international partners on numerous occasions on the economic dimension of the state's external affairs (Chagas-Bastos and Franzoni, 2019, October 16).

President Bolsonaro made an official state visit to China in October 2019 and hosted the $11^{\text {th }}$ BRICS summit in Brasília in November 2020. On these occasions he stressed the importance of the economic relations binding both states. He also gave a clear statement that Brazil would not participate in any trade wars and emphasized the relevance of the BRICS coalition in a changing global economic setup (Bolsonaro, 2019, November 14). When asked by a reporter about making deals with a communist state, he replied that China was a capitalist country (Senra, 2019, October 24). Also minister Araújo, when questioned in the United States about the mutual relationship with China, replied: "So I don't see at all in this sort of adversarial relationship with China, I think it's also cooperative relationship that can come in mutual benefit." (Araújo, 2019, September 11). As will be seen in the next section, however, his statements on China were less neutral in 2020, especially at the height of the pandemic crisis in Brazil.

The narrative on foreign policy proposed by Ernesto Araújo expresses the views of a part of Brazilian political elites in the Bolsonaro administration called anti-globalists, ideologists or "olavists" (olavistas) after the name of Olavo de Carvalho, a US-based self-appointed philosopher displaying his views on YouTube and ideological authority for the Bolsonaro family. Other important members of this group include Presidential Advisor on Foreign Affairs Filipe Martins, Minister of Environment Ricardo Salles, Minister of Education until June 2020 Abraham Weintraub, and federal deputy Eduardo Bolsonaro, the son of President Bolsonaro who is most engaged in foreign policy matters. The head of Itamaraty expressed in his inauguration speech the central role of Carvalho in shaping the outlines of Brazil's new foreign policy. The "ideological guru" of the Bolsonaro family has very clear and undiplomatic opinions on China's international position and the Sino-Brazilian relations, which can be summarized briefly as cutting ties with the communist state and supporting by all means the US in the new Cold War.

The roles of a faithful ally and defender of the faith promoted by Ernesto Araújo and Olavo de Carvalho are met with criticism by other important groups regarded as the pragmatic part of Bolsonaro's government - the military wing and the neoliberals. The first group is represented by Vice President Hamilton Mourão. Roles implying a negative approach towards China are also contested by Paulo Guedes, the influential Minister of Economy, and Tereza Christina, head of the Ministry of Agriculture representing the interests of the Brazilian agribusiness. On many occasions, Vice President Mourão attenuated the stand of the Brazilian government in interviews and speeches in an effort to pass the message that Brazil was considering China as a crucial interna-
Burning Bridges and Defending the Faith. The Troubled Brazil-China Partnership in the Bolsonaro Era

Monika Sawicka 
Dossier América Latina: la iniciativa china de la Franja y la Ruta tional partner (Stuenkel, 2019, May 13). A similar position was adopted by neoliberal politicians stressing the importance of trade relations and Chinese investments in infrastructure and the energy sector for a recovering economy. The ideology-driven roles of a defender of the faith and faithful ally are contested by a part of the political elites that perceive them as threatening to a partnership which was meticulously developed for over four decades. The next section will address how the new understanding of Brazil's western sense of belonging, epitomized through the enactment of both roles, triggered a new dynamic in Brazil's relations with the People's Republic of China.

\section{An asymmetric partnership falls out}

During the Workers' Party rule (2003-2010) Brazil and China created, in 2004, the China-Brazil Business Council (Conselho Empresarial Brasil-China, CEBC) to facilitate cooperation between Chinese and Brazilian enterprises, in 2006, the Sino-Brazilian High Level Commission on Conciliation and Cooperation (Comissão Sino-Brasileira de Alto Nivel de Conciliação e Cooperação, COSBAN), an important platform coordinating the relations between both sides and headed by the states' vice-presidents, and established in 2007 a Strategic Dialogue. Both countries also continued to develop a successful space program cooperation, launching satellites to monitor, for instance, the Amazon. ${ }^{10}$

With the creation of the BRICS and the BASIC ${ }^{11}$ coalition in global negotiations on climate change, Brazil and China gained new important platforms for cooperation. For Brazil, the membership in the BRICS along with China meant an increased visibility in international affairs and, what was particularly noticeable in the Dilma Rousseff years, the core instrument in Brazil's quest for a more prominent status. However, as Sean Burges observed:

[China] is both the key to Brazil's rise and the bane to its ambitions of becoming a truly global power (...). While Brazil's foreign policy establishment initially hoped that (...) Beijing would join it in a Southern alliance pushing for the global governance changes sought by Brasilia, events during the PT presidencies (...) have demonstrated that such expectations were overly optimistic. (Burges, 2017, p. 222)

During the presidencies of Lula and Dilma, China aligned with Brazil on trade negotiations with the WTO G20 group, the financial G20 demanding quota reforms within the International Monetary Fund and World Bank, and

10 The China-Brazil Earth Resources Satellite program was established in 1988, the last CBERS satellite was launched in 2019.

11 For an analysis of BRICS cooperation, see Stuenkel, 2015; Kirton \& Larionova, 2020. For an assessment of the BASIC negotiating position, see Hochstetler \& Milkoreit, 2015. 
a reluctance to share the burden of mitigating climate change. Nevertheless, most of these alliances proved less substantial and lasting than expected by policymakers in Brasília. Moreover, the Asian Giant adopted a strict "business first" outlook in matters of bilateral economic cooperation (Burges, 2017, pp. 230-231).

Since 2009, China is Brazil's main trading partner. After insignificant commercial exchanges in the 1980s, trade figures increased in the last decade of the $20^{\text {th }}$ century and began to skyrocket after the year 2000 .

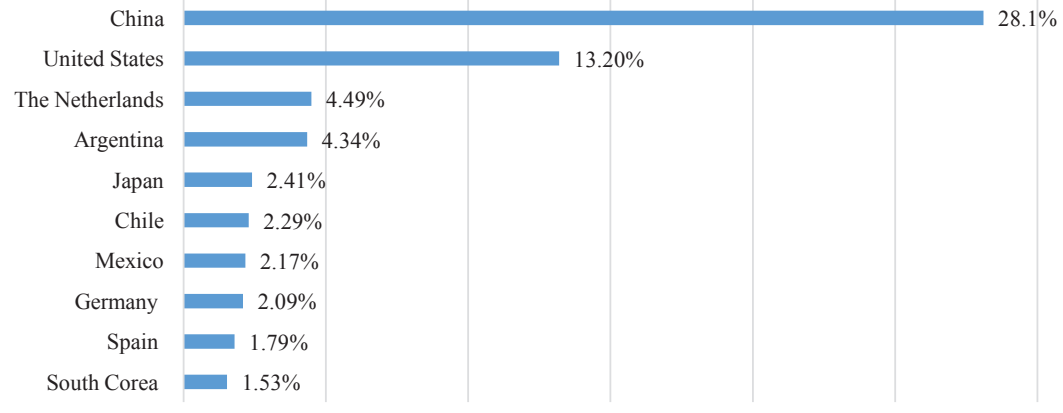

Source: MDIC, 2020.

Between 2001 and 2019 trade increased from USD 3.2 billion to USD 98.6 billion. Since 2009 Brazil also experienced an uninterrupted period of trade surplus, which reached in 2018 nearly USD 30 billion and in 2019 USD 28 billion.

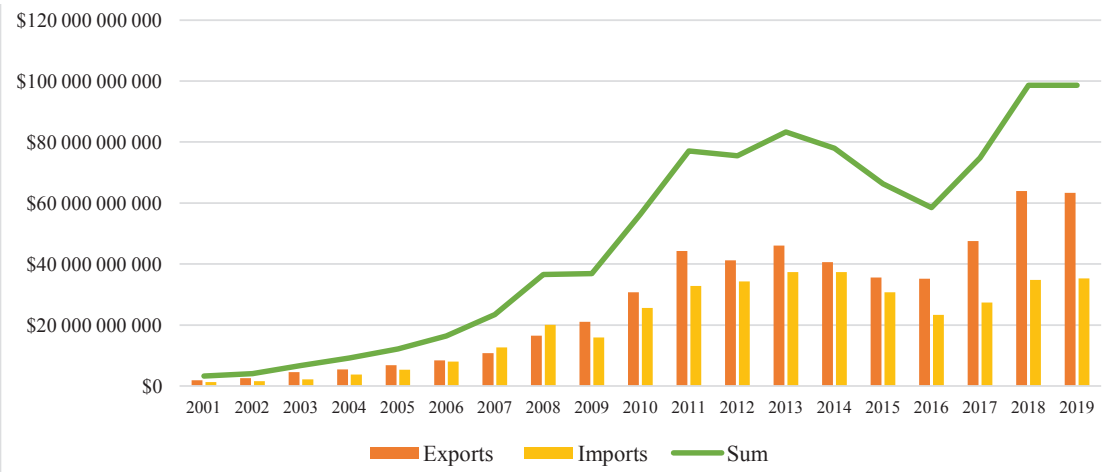

Source: MDIC, 2020.

Despite these impressive figures, the full picture seems to be more complex and justifies the perception of an asymmetric relation which is not all that beneficial. The portfolio of Brazilian exported items is not very extensive,
Burning Bridges and Defending the Faith. The Troubled Brazil-China Partnership in the Bolsonaro Era

Monika Sawicka

Chart 1.

Top ten Brazilian export destinations in 2019

\section{Chart 2.}

Sino-Brazilian trade figures 
Dossier América Latina: la iniciativa china de la Franja y la Ruta consisting mostly of three goods: soybeans (32\%), petroleum (24\%) and iron ore $(21 \%)$ (MDIC, 2020). The People's Republic of China purchases mainly raw materials and agricultural products and is responsible for a commodification of Brazil's exports after 2003. In 1997 primary goods made up for less than $30 \%$ of Brazilian exports; in the first four months of $2020-67 \%$ (Kramer, 2019, January 10; Passarelli, 2020, May 18). On the other hand, Brazil imports from China manufactured goods, including high-tech products: telecommunication equipment (12\%), transistors $(6 \%)$, platforms and other equipment for fluctuating structures (6\%) (MDIC, 2020). The Brazilian administration is also aware that China, especially until the trade war with the US, was less dependent on trade with Brazil than the other way round. ${ }^{12}$ The South American giant also lost market share in its manufactured products to strong Chinese competition in developing countries in Latin America, Africa, and the Middle East (Altemani de Oliveira, 2010, p. 95). Further, within Brazil Chinese imports of manufactured goods were not substitutes for more expensive products from the Global North but oftentimes competed directly with Brazilian equivalents (Jenkins, 2012, pp. 31-32).

Since 2009 Chinese investment in Brazil is also on the rise. In 2009 the China Development Bank offered a loan of USD 10 billion to the oil giant Petrobras and in 2010 seven Brazilian companies in the electric energy sector were purchased by the State Grid Corporation of China, the world's largest power company (Altemani de Oliveira, 2010, p. 96). In 2016 State Grid also purchased a controlling stake of Brazil's largest power distributor, CPFL (Montoya, Lemus \& Kaltenecker, 2019, p. 14). The CEBC estimated that the stock value of confirmed Chinese investment between 2007 and 2018 reached USD 58 billion and direct investment flows USD 3 billion in 2018. ${ }^{13}$ The main sectors receiving Chinese investment include energy, mining, automotive and finance, although in their latest report the CEBC noted that since 2014 the focus of the investors turns towards energy and infrastructure (Cariello, 2019 , p. 9). Most of the resources were directed to brownfield projects through mergers and acquisitions (Lapper, 2019, April 23). Yet Brazil did not express interest in joining the Latin American branch of the One Belt One Road Initiative. Brazil is one of the four Latin American states that so far did not join the gargantuan Chinese enterprise.

Chinese investments are important for Brazil in times when the country is struggling to recover after recession (the GDP contracted by $3.55 \%$ in 2015 and $3.47 \%$ in 2016 and reached meager growth rates since 2017). Contrary to previous practices, in recent years Chinese investors more commonly main-

12 Although the importance of Brazilian soybean supplies increased due to the trade war with the US and Brazil is currently China's main provider of this agricultural product and second-biggest supplier of iron-ore, in 2018 Brazil ranked $7^{\text {th }}$ among China's top destinations for exports. See: National Bureau of Statistics of China, 2019, table 11-5.

13 The values of confirmed and declared investment are USD 102.5 billion and USD 4.5 billion, respectively. 


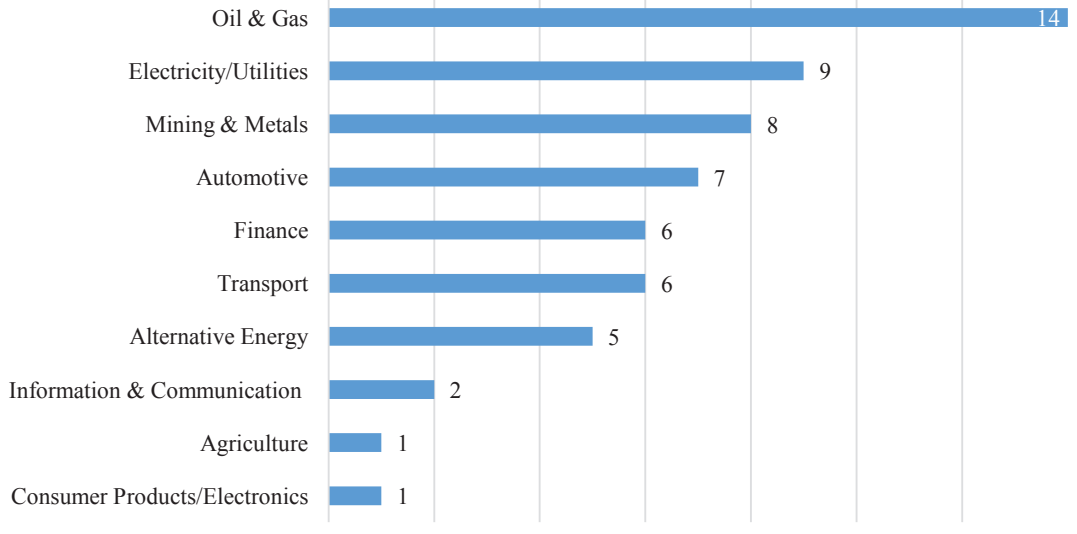

Source: Avendano, Melguizo \& Miner, 2017, p. 11.

tain and hire local workforce which is important in a country with the highest unemployment rate (11.9\% in 2018) in South America (CEPAL-OIT, 2020, p. 13). ${ }^{14}$ As the country struck by its worst economic crisis in history lacks the resources to develop its infrastructure, seen as one of the main obstacles in Brazil's growth, financial flows from Asia are not to be underappreciated.

Still, Chinese direct investment plunged from USD 8.8 billion to USD 3 billion between 2017 and 2018. ${ }^{15}$ This situation reflected the troubled relationship between Brazil and China. At the end of 2018 and in the first months of 2019 the partnership was put to test. In his presidential campaign Bolsonaro did not abstain from anti-Chinese comments. In the first half of 2019 the head of state and foreign affairs minister made at best moderate reflections on Brazil's partnership with the People's Republic of China.

Since the impeachment of President Dilma Rousseff in 2016, the countries suspended the COSBAN meetings, an important platform coordinating economic cooperation. During the presidential run, the far-right candidate manifested his dissent for acquisitions of land by Chinese investors or control over strategic industries. ${ }^{16}$ In March 2018, Bolsonaro with his sons made a visit to Taiwan. On that occasion the politician tweeted a critical comment about communist regimes which his administration would not embrace (Bolsonaro, 2018, March 5). In an op-ed published the day after Bolsonaro's election victory, the Chinese Global Times emphasized that contesting the "one China” prin-

14 The unemployment rate further rose to $12.9 \%$ between March and May 2020 due to the pandemic (IBGE, 2020).

15 The decline was even more significant when considering confirmed and declared investment flows: from USD 17.4 billion in 2017 to USD 4.5 billion in 2018.

16 For instance, the politician was a fierce critic of large-scale exports of niobium to China Brazil is in possession of $85 \%$ of world reserves (Lapper, 2019, April 23).
Burning Bridges and Defending the Faith. The Troubled Brazil-China Partnership in the Bolsonaro Era

Monika Sawicka

Chart 3.

Chinese FDI by industry between 2003 and 2016 (in USD billions) 
Dossier América Latina: la iniciativa china de la Franja y la Ruta ciple would "cost Brazil a great deal" (Global Times, 2018, October 29). Before his first visit to the US in March 2019, President Bolsonaro made a comment about the necessity to reformulate Brazilian trade relations as they would be no longer impacted by ideological factors. His son Eduardo Bolsonaro was more explicit, summarizing Sino-Brazilian trade exchange as ideology-driven (Lima, 2019, March 26). The sense of tension became palpable when China blocked the first disbursement of USD 10 billion from the Brasil-China Cooperation Fund, set up in 2015 to finance infrastructure projects in Brazil (Rittner \& Kruger, 2019 March 7). According to Oliver Stuenkel, at the beginning of 2019 relations faced its most difficult moment in history (Stuenkel, 2019, May 22). Despite these strains, in January 2019 Chinese authorities invited members of then-presidential party PSL for a visit to China and in May 2019 Hamilton Mourão made a trip to Beijing. His task was to improve the tarnished image of Brazil by convincing the Chinese government that pragmatic forces within the Brazilian administration were in control of the situation, able to restrain attitudes which could damage bilateral relations. His visit also led to a reactivation of COSBAN.

President Bolsonaro met the Chinese leader during the BRICS informal leaders meeting on the margins of the G20 conference in Osaka in June 2019, ${ }^{17}$ made a state visit to China in October and received the Chinese head of state in Brasília for the $11^{\text {th }}$ BRICS summit in November. During the visit to Beijing both countries signed 11 agreements, including cooperation in the areas of infrastructure, oil and gas, and agriculture. President Bolsonaro also invited two Chinese companies to the country's biggest oil tender in history. The October and November visits allowed to reach important agreements opening market access for Brazilian agricultural products, including meat. Due to increased Chinese demand for Brazilian beef, Brazil reached record levels of beef exports in 2019 (Landim, 2019, October 25).

At the end of 2019, the Sino-Brazilian relations seemed to have had improved. What once again led to an escalation of tensions and even diplomatic crisis in March 2020 was the outbreak of the COVID-19 pandemic. Brazil is as of writing the second country with the highest confirmed number of coronavirus cases and members of the radical wing within the Bolsonaro administration together with federal deputy Eduardo Bolsonaro used social media to launch hostile comments blaming the People's Republic of China for the global health crisis. Former Minister of Education Abraham Weintraub's April 2020 tweet - apart from mocking the Chinese accent - displayed the author's belief in conspiracy theories of China's geopolitical inter-

${ }^{17}$ It is noteworthy that in Osaka Presidents Xi Jinping, Vladimir Putin and Indian Prime Minister Narendra Moody also held a trilateral summit, excluding Brazil and South Africa. This was the third time such meeting was held between the leaders since 2018 and it might be a signal of decreased interest for cooperation within the BRICS, placing crisis-ridden Brazil as a secondtier partner (Aneja, 2019, June 24). 
ests in spreading the virus (Weintraub, 2020, April 4). What was met with an unprecedented reaction from Chinese diplomatic representatives in Brazil were Eduardo Bolsonaro's March 2020 tweets. The federal deputy compared the pandemic crisis to the Chernobyl catastrophe, blaming the communist regime for hiding the truth about the pandemic after its outbreak and stating that "liberty is the solution" (Bolsonaro, 2020, March 18). The message caused an immediate reaction on the Twitter accounts of Chinese ambassador Yang Wanming and the embassy. Hamilton Mourão and Ernesto Araújo also stepped in and underlined in interviews that the deputy's opinion did not reflect the official position of the government. Their reactions were followed by the Congress, the Brazilian Lower House issued a letter of apology. The head of the Brazilian diplomacy, however, defended the deputy's point of view and in recent months Araújo himself made critical comments about the communist regime. ${ }^{18}$ In April 2020 the General Consul of China in Rio de Janeiro criticized Eduardo Bolsonaro for his Sinophobia, emphasizing that his statements could harm bilateral relations. The sentence "If any country insists on being China's enemy, we will be its most competent enemy!" (Yang, 2020, April 4) reverberated in Brazilian media for days. The Chinese outspoken reaction made it clear that Brazil's Asian partner was becoming more assertive and less willing to ignore comments of influential anti-Chinese politicians.

The antagonistic discourse has also more tangible consequences. Brazil is in dire need of medical equipment including ventilators; however, attempts to purchase these goods from China have either fallen through or the shipments got stuck due to bureaucratic clearance, forcing the Brazilian authorities to search for alternative suppliers. These difficulties coincided with the diplomatic crisis (Mattos, 2020, April 8). In June 2020, the Chinese government decided to block meat imports from several production plants in Brazil due to COVID-19 cases among slaughterhouse workers. Although the measure is a sanitary precaution, which impacted also other countries, Brazil's negotiating position with its biggest importer of beef, pork and poultry has been significantly weakened due to the offensive comments in social media. What could leverage Brazil's position in discussions with China is the planned bidding to set up the 5G network in Brazil. Since 2019, the Trump administration pressured the Brazilian authorities to ban the Chinese Huawei from participating in the tender that was planned for 2020 but has been postponed to 2021 due to the pandemic. The vice president, minister of agriculture and speaker of the Lower House criticized such idea - in July 2020 Hamilton Mourão repeated his view that it would be difficult to exclude Huawei from the bidding as the company owned a significant part of the $4 \mathrm{G}$ infrastructure, a baseline for the

18 On his personal blog, Minister Araújo posted an essay titled "The comunavirus arrived" (Chegou o comunavirus) in which he reflects on the global communist threat which in times of the pandemic is more real than ever before (Araújo, 2020, April 22). 
Dossier América Latina: la iniciativa china de la Franja y la Ruta implementation of the 5G technology (Marcello, 2020, July 15). Whether the Brazilian government will be able to use the $5 \mathrm{G}$ card wisely remains an open question. ${ }^{19}$

\section{Conclusions}

From the first days, the Bolsonaro administration attracted the attention of scholars interested in the new direction of the country's foreign policy. Analyzing presidential and ministerial declarations and initiatives, researchers made first assessments about the levels of pragmatism and ideology in Brazil's external affairs (Gomes Saraiva \& Costa e Silva, 2019), identified its shift from pivotal to proxy state and the new principle of rigid Occidentalism (Pereyra Doval \& Ordoñez, 2020), double dependency from Washington and Beijing (Actis, 2019) and even mocked the new foreign policy by calling Brazil the dumb giant (Chagas-Bastos \& Franzoni, 2019, October 16). This paper sought to build upon the existing literature and contribute to the developing discussion by emphasizing the changing understanding of Brazil's sense of belonging and its impact on the relationship with Brazil's important partner.

The article elaborated on the relation between the Brazilian identity and its national role conceptions which were redefined by the current administration. The major shift of Brazil's discursive self-articulation conducted by the anti-globalist wing of the Brazilian foreign policy elites translated into new narratives about foreign policy. These narratives contained a new vision of the global order, reformulated partnerships, and policy strategies, although a great part of this vision remains unclear and confuse. Politicians such as Jair Bolsonaro, Ernesto Araújo, Eduardo Bolsonaro, and Abraham Weintraub share the perception of an international system which became the stage for the clash of civilizations. A redefined self-conception, including a different vision of Ego-Alter relations with the country's Significant Others, resulted in role change - the location of new roles for Brazil. The central axis of Brazil's identity reformulation is anchored in the notion of a West which is facing an unprecedented crisis. Brazil, an unquestioned member of the occidental world, is at the forefront of this battle as the defender of the faith and faithful ally of the United States. These new or rediscovered roles have taken their toll on Brazil's relationship with China.

The Sino-American trade war which started in 2018 increased the importance of Brazil as a Chinese supplier of agricultural products and soybean in particular, yet the analysis of the past 18 months leads to the conclusion that

\footnotetext{
19 Further diplomatic escalations with the People's Republic of China might put Brazil on the spot where policymakers will need to appease China by excluding the option of banning Huawei - the declarations of Hamilton Mourão can be understood as a signal of such approach.
} 
Brazil so far has not been able to turn these tensions to its advantage. At the end of 2019 Brazil seemed to have overcome the negative reverberations left by the presidential race when candidate Bolsonaro manifested anti-Chinese sentiments. Both states reached numerous agreements allowing to further deepen their trade and investment relation. Despite the existing asymmetries, this cooperation is still of fundamental value for an economy struggling to recover after its worst crisis in history. Yet, the poor management of the pandemic emergency triggered a blame-shifting attitude among important policymakers in Brasília and was an opportunity to vent Sinophobic emotions which in recent years spread among the Brazilian society, including the rightwing electorate (Pinheiro-Machado, 2020, June 27). To ease the recent strains, the Bolsonaro administration might have to make concessions to China, diminishing Brazil's bargaining potential.

Presidential Advisor on Foreign Policy, Filipe Martins, in an online conference organized by Brazilian think-tank The Alexandre de Gusmão Foundation (FUNAG) in June 2020 claimed that since the 2018 elections the SinoBrazilian relationship „has been raised to a higher level of maturity. A level which allows us to speak equal to equal.” (Martins, 2020, June 23). Such statement diverges from a reality in which Brazil remains an international player shaken by a political, health, and economic crisis and an actor increasingly dependent on Chinese trade and investment. During World War II the Getúlio Vargas administration skillfully maneuvered between both antagonistic blocs refusing to take sides for as long as possible, what resulted in beneficial economic concessions. This remark is not to glorify a highly controversial statesman. It rather suggests that the current administration should reconsider its foreign policy and draw important conclusions from the country's past diplomatic successes. Such exercise requires a reassessment of the advantages which strategic equidistance between antagonized players might bring to neutral powers.

\section{References}

Actis, E. (2019). La visión del mundo de Jair Bolsonaro. Foreign Affairs Latinoamérica, vol. 19, no. 1, pp. 51-57.

Aggestam, L. (2006). Role theory and European foreign policy: A framework of analysis. In O. Elgström and M. Smith (eds.), The European Union's Roles in International Politics: Concepts and Analysis, London: Routledge.

Alencastre, A. (1961). Oswaldo Aranha, o mundo afro-asiático e a paz. Rio de Janeiro: Ministério de Trabalho e Previdência Social.

Altemani de Oliveira, H. (2010). Brasil e China: uma nova aliança não escrita?. Revista Brasileira de Política Internacional, vol. 53, no. 2, pp. 88-106.

Andrade, O. (1928). Manifesto antropófago.
Burning Bridges and Defending the Faith. The Troubled Brazil-China Partnership in the Bolsonaro Era

Monika Sawicka 
Dossier América Latina: la iniciativa china de la Franja y la Ruta
Aneja, A. (2019, June 24). Modi, Xi, Putin to meet in Osaka. The Hindu. Retrieved July 16, 2020, from https://www.thehindu.com/news/international/modi-xi-putin-to-meet-inosaka/article28123557.ece

Araújo, E. (2020, April 22). Chegou o Comunavírus. Metapolítica 17: Contra o globalismo (blog), Retrieved July 15, 2020, from https://www.metapoliticabrasil.com/post/chegou-ocomunav\%C3\%ADrus

Araújo, E. (2019, December 13). A Nova Política Externa Brasileira, Luanda, Retrieved July 14, 2020, from http://www.itamaraty.gov.br/pt-BR/discursos-artigos-e-entrevistascategoria/ministro-das-relacoes-exteriores-discursos/21162-a-nova-politica-externabrasileira-luanda-angola-13-12-2019

Araújo, E. (2019, September 11). "Brazil is back" - Discurso do Ministro das Relações Exteriores na Heritage Foundation. Washington. Retrieved July 14, 2020, from http://www. itamaraty.gov.br/pt-BR/discursos-artigos-e-entrevistas-categoria/ministro-das-relacoesexteriores-discursos/20880-brazil-is-back-discurso-do-ministro-das-relacoes-exterioresna-heritage-foundation-washington-11-de-setembro-de-2019-original-em-ingles

Araújo, E. (2019, June 10). Discurso do senhor ministro de Estado por ocasião da abertura do seminário sobre "Globalismo" da FUNAG. Palácio Itamaraty. Retrieved July 14, 2020, from http://www.itamaraty.gov.br/pt-BR/discursos-artigos-e-entrevistas-categoria/ministrodas-relacoes-exteriores-discursos/20512-discurso-do-senhor-ministro-de-estado-porocasiao-da-abertura-do-seminario-sobre-globalismo-da-funag-palacio-itamaraty-10-dejunho-de-2019.

Araújo, E. (2019, March 11). Aula magna do ministro de Estado das Relações Exteriores, embaixador Ernesto Araújo, no Instituto Rio Branco. Brasília. Retrieved July 14, 2020, from http://funag.gov.br/index.php/pt-br/component/content/article?id=2912

Araújo, E. (2019, January 2). Discurso do ministro Ernesto Araújo durante cerimônia de Posse no Ministério das Relações Exteriores. Brasília. Retrieved July 14, 2020, from http://www. itamaraty.gov.br/pt-BR/discursos-artigos-e-entrevistas-categoria/ministro-das-relacoesexteriores-discursos/19907-discurso-do-ministro-ernesto-araujo-durante-cerimonia-deposse-no-ministerio-das-relacoes-exteriores-brasilia-2-de-janeiro-de-2019

Araújo, E. (2017). Trump e o Ocidente. Cadernos de Política Exterior, ano III, no. 6, segundo semestre, pp. 323-357.

Araújo Castro, J. A. de (2007). Relatório do ministro João Augusto de Araújo Castro, observador do Brasil à Reunião Preliminar da Conferência de Chefes de Estado e Governo de Países Não-Alinhados, Documento 12. In A. C. Franco (org.), Documentos da Política Externa Independente, vol. I, Brasília: FUNAG, pp. 94-115.

Avendano, R., Melguizo A. \& Miner S. (2017). Chinese FDI in Latin America: New trends with global implications. Atlantic Council and OECD.

Below, A. (2015). Environmental Politics and Foreign Policy Decision Making in Latin America Ratifying the Kyoto Protocol. London: Routledge.

Beneš, V. \& Harnisch, S. (2015). Role theory in symbolic interactionism: Czech Republic, Germany and the EU. Cooperation and Conflict, vol. 50, no. 1, pp. 146-165.

Bethell, L. (2009). O Brasil e a ideia de "América Latina" em perspectiva histórica. Estudos Históricos, vol. 22, no. 44, pp. 289-321.

Bezerra de Menezes, A.J. (2012). O Brasil e o Mundo Ásio-Africano. Brasília: FUNAG.

Bolsonaro, E. (2020, March 18), Quem assistiu Chernobyl [Tweet]. Retrieved July 27, 2020, from, https://twitter.com/bolsonarosp/status/1240286560953815040?lang=en 
Bolsonaro, J.M. (2019, November 14), Transcrição do discurso do Presidente da República, Jair Bolsonaro, na Sessão Plenária da $11^{a}$ Cúpula do BRICS. Brasília. Retrieved July 27, 2020, from http://brics2019.itamaraty.gov.br/espaco-multimidia/noticias/116-transcricao-do-discursodo-presidente-da-republica-jair-bolsonaro-na-sessao-plenaria-da-11-cupula-do-brics

Bolsonaro, J.M. (2019, January 1), Discurso do Presidente da República, Jair Bolsonaro, durante Cerimônia de Posse no Congresso Nacional. Brasília. Retrieved July 17, 2020, from http://www. itamaraty.gov.br/pt-BR/discursos-artigos-e-entrevistas-categoria/presidente-da-republicafederativa-do-brasil-discursos/19887-discurso-do-presidente-da-republica-jair-bolsonarodurante-cerimonia-de-posse-no-congresso-nacional-brasilia-1-de-janeiro-de-2019

Bolsonaro, J.M. (2018, March 5). Nossa passagem por... [Tweet]. Retrieved March 6, 2020, from https://twitter.com/jairbolsonaro?lang=en

Burges, S.W. (2017). Brazil in the world: The international relations of a South American giant. Manchester: Manchester University Press.

Cantir C. \& Kaarbo, J. (2016). Unpacking Ego in Role Theory: Vertical and Horizontal Role Contestation and Foreign Policy. In C. Cantir \& J. Kaarbo (eds.), Domestic Role Contestation, Foreign Policy, and International Relations. London: Routledge.

Cariello, T. (2019). Investimentos Chineses No Brasil 2018: O quadro brasileiro em perspectiva global. Rio de Janeiro: CEBC.

CEPAL-OIT (2020). Coyuntura Laboral en América Latina y el Caribe: El trabajo en tiempos de pandemia: desafíos frente a la enfermedad por coronavirus (COVID-19). Boletín CEPALOIT, no. 22, Santiago de Chile.

Chagas-Bastos F. H. \& Franzoni M. (2019, October 16). The Dumb Giant: Brazilian Foreign Policy under Jair Bolsonaro. Retrieved July 15, 2020, from https://www.e-ir.info/2019/10/16/ the-dumb-giant-brazilian-foreign-policy-under-jair-bolsonaro/

Charner, F. (2019, June 26). Officer traveling with Brazilian president Bolsonaro caught with 39 kilos of cocaine. CNN. Retrieved July 9, 2020, from https://edition.cnn.com/2019/06/26/ americas/brazil-officer-cocaine-g20-intl/index.html

Fortín, C., Heine J. \& Ominami C. (2020). Latinoamérica: no alineamiento y la segunda Guerra Fría. Foreign Affairs Latinoamérica, vol. 20, no. 3, pp. 107-115.

Gambini, R. (1977). O duplo jogo de Getúlio Vargas. São Paulo: Símbolo.

Global Times (2018, October 29). Will new Brazilian government reverse China policy?. Retrieved July 27, 2020, from https://www.globaltimes.cn/content/1124948.shtml

Gomes Saraiva, M. \& Costa Silva A.V. (2019). Ideologia e pragmatismo na política externa de Jair Bolsonaro. Relações Internacionais, no. 64, pp. 117-137.

Hochstetler, K. \& Milkoreit, M. (2015). Responsibilities in transition: Emerging powers in the climate change negotiations. Global Governance, vol. 21, no. 2, pp. 205-226.

Holsti, K. (1970). National Role Conceptions in the Study of Foreign Policy. International Studies Quarterly, vol. 14, no. 3, pp. 233-309.

IBGE (Instituto Brasileiro de Geografia e Estatística). (2020). Taxa de desocupação no trimestre (encerrado em maio de 2020). PNAD Continua. Retrieved July 18, 2020, from www.ibge.gov.br

Jaguaribe, H. (2013). O Nacionalismo na atualidade brasileira. Brasília: FUNAG.

Jenkins, R. (2012). China and Brazil: Economic Impacts of a Growing Relationship. Journal of Current Chinese Affairs, vol. 41, no. 1, pp. 21-47.
Burning Bridges and Defending the Faith. The Troubled Brazil-China Partnership in the Bolsonaro Era

Monika Sawicka 
Dossier América Latina: la iniciativa china de la Franja y la Ruta
Karim, M.F. (2018). Middle power, status-seeking and role conceptions: the cases of Indonesia and South Korea. Australian Journal of International Affairs, vol. 72, no. 4, pp. 343-363.

Kirton, J. \& Larionova M. (eds.). (2020). BRICS and Global Governance. London and New York: Routledge.

Kramer, V. (2019, January 10). Quase metade do que o Brasil exporta é de produto básico. E tão cedo não vai mudar. Gazeta do Povo. Retrieved July 18, 2020, from https://www. gazetadopovo.com.br/economia/quase-metade-do-que-o-brasil-exporta-e-de-produtobasico-e-tao-cedo-nao-vai-mudar-brs3jmsiu1696wbu03n6tjuco/

Landim, R. (2019, October 25). China deve liberar exportação de carne processada do Brasil. Folha de S. Paulo. Retrieved July 27, 2020, from https://wwwl.folha.uol.com.br/ mercado/2019/10/china-deve-liberar-exportacao-de-carne-processada-do-brasil.shtml

Lapper, R. (2019, April 23). Bolsonaro Took Aim at China. Then Reality Struck. Americas Quarterly. Retrieved July 15, 2020, from https://www.americasquarterly.org/article/ bolsonaro-took-aim-at-china-then-reality-struck/

Lima, J.A. (2019, March 26). Governo Bolsonaro manda sinais confusos a Pequim. Deutsche Welle. Retrieved July 14, 2020, from https://www.dw.com/pt-br/governo-bolsonaromanda-sinais-confusos-a-pequim/a-48068352

Love, J. L. (1994). Economic ideas and ideologies in Latin America since 1930. In L. Bethell (ed.), The Cambridge history of Latin America, vol. VI. Latin America since 1930: Economy, society and politics, New York: Cambridge University Press.

Marcello, M.C. (2020, July 15). Mourão considera difícil banir a Huawei do leilão de 5G. UOL. Retrieved July 28, 2020, from https://noticias.uol.com.br/ultimas-noticias/ reuters/2020/07/15/mourao-considera-dificil-banir-a-huawei-do-leilao-de-5g. htm? cmpid=copiaecola

Martinez, L.C. (1970). Communist China's Policy Toward Latin-America. Naval War College Review, vol. 23, no. 3, pp.79-98.

Martins, F.G. (2020, June 23). Brasil e China. Conferência online: Conjuntura internacional no pós-coronavírus. FUNAG. Retrieved July 16, 2020, from https://www.youtube.com/ watch?v=HBP_G5oPcpY

Mattos, R. (2020, April 8). Em meio a atrito, Brasil negocia com a China equipamentos contra covid-19. UOL. Retrieved July 28, 2020, from https://noticias.uol.com.br/saude/ ultimas-noticias/redacao/2020/04/08/em-atrito-com-china-brasil-ja-tinha-problemaspara-comprar-insumos.htm? cmpid=copiaecola

MDIC (2020). Balança comercial por países e blocos: China. Retrieved July 18, 2020, from http://comexstat.mdic.gov.br/pt/comex-vis

Merquior, J.G. (1990). O Outro Ocidente. Presença: Revista de Política e Cultura, no. 15, pp. 69-91.

Montoya M.A., Lemus, D. \& Kaltenecker, E. (2019). The Geopolitical Factor of Belt and Road Initiative in Latin America: The cases of Brazil and Mexico. Latin American Journal of Trade Policy, vol. 2, no. 5, pp. 6-21.

Moura, G. (1980). A Autonomia na dependência: a política externa brasileira de 1935 a 1942. Rio de Janeiro: Editora Nova Fronteira.

National Bureau of Statistics of China (2019). Table 11-5: Value of Imports and Exports by Country (Region) of Origin/Destination (2018). China Statistical Yearbook 2019. Retrieved July 27, 2020, from http://www.stats.gov.cn/tjsj/ndsj/2019/indexeh.htm 
Passarelli, H. (2020, May 18). Commodities ganham espaço e já são 67\% das exportações. Valor Econômico. Retrieved July 16, 2020, from https://valor.globo.com/brasil/ noticia/2020/05/18/commodities-ganham-espaco-e-ja-sao-67-das-exportacoes.ghtml

Pereyra Doval G. \& Ordoñez E. (2020). De pivote a proxy. Foreign Affairs Latinoamérica, June. Retrieved July 3, 2020, from http://revistafal.com/de-pivote-a-proxy/

Pinheiro-Machado, R. (2020, June 27). Sinofobia já é um fenômeno global. El País (Brasil). Retrieved July 28, 2020, from https://brasil.elpais.com/opiniao/2020-06-27/sinofobia-ja-eum-fenomeno-global.html

Quadros, J. (1961). Brazil's New Foreign Policy. Foreign Affairs, vol. 40, no. 1, pp. 19-27.

Rittner, D. \& Krüger, A. (2019, March 7). Retórica anti-China trava uso de fundo bilionário no Brasil. Valor Econômico. Retrieved July 14, 2020, from https://valor.globo.com/brasil/ noticia/2019/03/07/retorica-anti-china-trava-uso-de-fundo-bilionario-no-brasil.ghtml

Rodrigues, J.H. (1965). Brazil and Africa, trans. R.A. Mazzara, S. Hileman. Berkeley: UC Press.

Sá Guimarães, F. (2020). The uneasy 'well-placed' state: Brazil within Latin America and the West. Cambridge Review of International Affairs. https://doi.org/10.1080/09557571.2 020.1723059

Sá Guimarães, F. (2019, November 20). Far-Right Populism and Foreign Policy Identity: Evidence from Bolsonaro's Ultra-Conservative Foreign Policy in Brazil. Lecture held at Brown University. Retrieved July 12, 2020, from https://www.youtube.com/watch?v=ttHhorSMo hk\&feature=youtu.be

Santos, N.B. (2002). A dimensão multilateral da política externa brasileira: perfil da produção bibliográfica. Revista Brasileira de Política Internacional, vol. 45, no. 2, pp. 26-45.

Saraiva Guerreiro, R. (2010). Ramiro Saraiva Guerreiro (depoimento, 1985). Rio de Janeiro: CPDOC.

Selcher, W. (1978). Brazil's Multilateral Relations between First and Third Worlds. Boulder, Colorado: Westview Press.

Senra, R. (2019, October 24). "Estou num país capitalista", diz Bolsonaro ao chegar à China. BBC. Retrieved July 27, 2020, from https://www.bbc.com/portuguese/brasil-50165787

Skidmore, T.E. (1999). Brazil. Five Centuries of Change. New York, Oxford: Oxford University Press.

Soares de Lima, M.R. (1996). Brazil's Response to the "New Regionalism". In G. Mace \& J. P. Thérien, Foreign Policy and Regionalism in the Americas. Boulder, Colorado: Lynne Rienner Publishers.

Stuenkel, O. (2015). The BRICS and the Future of the Global World Order. Lanham: Lexington.

Stuenkel, O. (2011). Identity and the concept of the West: the case of Brazil and India. Revista Brasileira de Política Internacional, vol. 54, no. 1, pp. 178-195.

Stuenkel O. (2019, May 22). Mourão será capaz de consertar as relações entre Brasil e China?. Época. Retrieved July 16, 2020, from https://epoca.globo.com/mourao-sera-capazde-consertar-as-relacoes-entre-brasil-china-23684766

Stuenkel, O. (2019, May 13). Mourão em Pequim poderá elevar patamar das relações BrasilChina. El País. Retrieved July 19, 2020, from https://brasil.elpais.com/brasil/2019/05/13/ opinion/1557764948_144679.html
Burning Bridges and Defending the Faith. The Troubled Brazil-China Partnership in the Bolsonaro Era

Monika Sawicka 
Dossier América Latina: la iniciativa china de la Franja y la Ruta
Szacki, J. (2004). O tożsamości (zwłaszcza narodowej) [On identity (in particular, the national one)]. Kultura i Społeczeństwo [Culture and Society], no. 3, pp. 9-40.

Thies, C. (2010). Role Theory and Foreign Policy. In R. A. Denemark (ed.), The International Studies Encyclopedia. London: Blackwell, pp. 6335-6356.

Wehner, L. (2018). The narration of roles in foreign policy analysis. Journal of International Relations and Development, vol. 23, no. 2, pp. 359-384.

Wehner, L. \& Thies, C. (2014). Role theory, narratives and interpretation: the domestic contestation of roles. International Studies Review, vol. 16, no. 3, pp. 411-436.

Weintraub, A. (2020, April 4). Geopolíticamente, quem poderá sair fortalecido... [Tweet]. Retrieved April 6, 2020, from https://www1.folha.uol.com.br/mundo/2020/04/weintraub-usacebolinha-da-turma-da-monica-para-fazer-chacota-de-chineses.shtml, access: 06.04.2020.

Yang, L. (2020, April, 4). Valorize as relações China-Brasil, deputado Eduardo. O Globo. Retrieved July 28, 2020, from https://oglobo.globo.com/opiniao/artigo-valorizeas-relacoeschina-brasildeputado-eduardo-24350358 